\title{
KONCEPTUÁLNÍ PŘÍSTUP V TÉMATU ZOBRAZOVÁNÍ KŘíŽOVÉ CESTY
}

\author{
HANA LAMATOVÁ \\ Katedra dějin umění, Filozofická fakulta Univerzity Palackého v Olomouci \\ E-mail: hanakala@hotmail.com
}

\begin{abstract}
Display of the Stations of the Cross and the conceptual approach

The perception of the Stations of the Cross is constantly oscillating between visual perception and the acceptance of a verbal description. In the beginning, people taking part in historical events (Jesus Christ went to the execution with the cross in the streets of Jerusalem) perceived and experienced what others later tied to words. (Leaving aside the oral history, the first biblical text appeared in the 1st century, and the text tradition of records of the Stations of the Cross's piety dates back to 1471.) An effort to convey the described historical event through the senses meant adding an image to the text (for the first time in 1423 or 1425). The long period of coexistence of the verbal description and the corresponding visual concepts was gradually disrupted by artists during the 20th century until its last decades in which the artists almost achieved independence of an image from the traditional theme. They did it through an emphasis on expressing inner reality and overcoming the subject reality. They created a new system of symbols suppressing the traditional Stations of the Cross's image. This artistic concept sees a creative role in the hands of the subject, both the author of the work and his observer. As an accompaniment to this new image, another verbal description appears interpreting blank spaces between the work and the recipient. This transformation will be interpreted on the several artworks.

Keywords: Czech art of the 21th century; Display of the Stations of the Cross; Conceptualization of a traditional motif; Transformation of a perception the sacral art pieces
\end{abstract}

Kulturní fenomén křrižové cesty můžeme v zásadě vnímat dvěma různými způsoby, ve formě vizuální informace nebo slovního popisu. Zdroj tématu ovšem leží na jiném základě, stala se jím v historii ukotvená událost ze života Ježíše Krista. Její účastníci vnímali a zažívali, co později další spoutali do slov. Snaha zprostředkovat popisovaný děj co do smyslové bezprostřednosti pak znamenala doplnění textu obrazem. Následně zaznamenáváme dlouhé období oboustranně výhodné koexistence slovního popisu a tomu odpovídající vizuální představy křížové cesty. To bylo ovšem v průběhu 20. století postupně narušováno umělci, kteří dosáhli v posledních desetiletích zdánlivé nezávislosti výtvarného zobrazení na textovém popisu. Je tedy na místě se ptát nejen jakým způsobem tato změna probíhala, ale také jaké důsledky s sebou přinesla.

Zbožnost křížové cesty byla dlouhou tradicí kultivována do charakteristické podoby čtrnácti navazujících zastavení vyprávějících o poslední cestě Ježíše Krista s křrižem na bedrech až na místo popravy. Je tak nositelkou důležitých kulturních a duchovních významů. V prologu Janova evangelia se praví, že na počátku bylo Slovo, ${ }^{1}$ ovšem v tomto

$1 \quad$ Jan 1,1 
tématu je důležité si uvědomit, že kř́ižová cesta, nebo také cesta bolesti, jako záznam události ze života Ježíše Krista byla před slovním popisem prožitá a vnímaná. Jejími prvními účastníky se vedle nejdůležitější postavy Božího Syna stali členové zástupu, který ho následoval pravděpodobně v pátek 7 . dubna roku $30 \mathrm{n}$. 1. ulicemi Jeruzaléma. ${ }^{2}$ Svědectví o této události se předávalo zřejmě nejprve ústně a přibližně o 40 let později bylo poprvé zapsáno v Markově evangeliu. ${ }^{3}$

Textové zprávy nás také informují o prvních pokusech procházet stejnou cestu, jakou absolvoval Ježíš Kristus na Golgotu. Ve 3. století pátral po Ježíšových stopách Órigenés a od 4. století se začali ulicemi Jeruzaléma procházet křestanští poutníci. ${ }^{4}$ Vznikaly spisy zachycující poutnickou zkušenost a zároveň meditativní texty, zaměřující se na důkladný popis pašijových událostí. ${ }^{5}$ Až v 15. století byla kodifikována vlastní zbožnost křízové cesty. První knihu Stationsbüchlein (Knížk zastavení) sepsal v roce 1471 nizozemský duchovní Betlem. ${ }^{6}$ Její postupná evoluce byla zakončena v polovině 18 . století díky osobnosti Leonarda da Porto Maurizio (1676-1751). Ten v souladu s prvním textem předložil věřícím představu, že Ježíš Kristus zůstal na své pouti s křížem od domu Piláta na Kalvárii čtrnáctkrát stát, a charakterizoval zastavení, která jsou stále aktuální. ${ }^{7}$

Zmíněné spisy neměly jen charakter záznamu určitého druhu paměti, ale podílely se na spoluutváření duchovního prožitku, $\mathrm{k}$ němuž se přidala výtvarná vizualizace, aby opět akcentovala smyslovou bezprostřednost. V Evropě se tak poprvé stalo v roce 1423 (či 1425) při klášteře Scala Coeli u španělské Córdoby. ${ }^{8}$ Od této doby je možné pozorovat koexistenci textového a vizuálního popisu ve vzájemném kauzálním vztahu, ve kterém vizualita čerpá po formální i obsahové stránce textu.

Proměna zobrazování v námětu křížové cesty, jež zde bude alespoň částečně analyzována na několika vybraných př́ikladech, nastoupila v průběhu 20. století a nejmarkantněji

2 Gerhard Kroll, Po stopách Ježišových, Kostelní Vydří 2002, s. 348. - James D. Douglas (ed.), Nový biblickýslovník, Praha 2009, s. 425.

3 Kurt Schubert, Bible a dějiny, Svitavy 2000, s. 11-24, 46-52.

4 Franz Dambeck, Heslo Kreuzweg (Kř́žová cesta), in: Engelbert Kirschbaum (ed.), Lexikon der christlichen Ikonographie: allgemeine Ikonographie. Bd. 2, Fabelwesen-Kynokephalen, Rom 1990, sl. 653-656, cit. sl. 653.

5 Anselmus Cantuariensis, Dialogus Beatae Mariae Et Anselmi De Passione Domini, Documenta Catholica Omnia, MPL159, sl. 271A-290A, http://www.documentacatholicaomnia.eu/02m/1033-1109, _Anselmus_Cantuariensis,_Dialogus_Beatae_Mariae_Et_Anselmi_De_Passione_Domini _[Incertus],_MLT.pdf, vyhledáno 20.12.2017. - Bernardus Claraevallensis, Liber de passione christi et doloribus et planctibus matris ejus (D. Eugenius de Levis, Anecdota sacra, p. 60. Augustae Taurinorum 178...40.). - Bonaventura, Meditationes de passione Christi, in: Iohannes de Caulibus, Meditationes uitae Christi, Augsburg 1468. - Iohannes de Caulibus, Meditationes uitae Christi, Augsburg 1468. - Heinrich Seuse, Büchlein der ewigen Weisheit. Die 100 Betrachtungen, Schwaben [Weinsberg?] 2. čtvrtina 14. století. - Pseudo-Beda, De meditatione passionis Christi per septem dici boros libellus, in: Martha Bayless (ed.), Collectanea pseudo-Bedae, Dublin 1998. - Jan Pascha, Pelgrimsreis naar het heilige land (Peregrinatio spiritualis), Brussel 1593 [?]. - Christiaan van Adrichem, Iervsalem, sicvt Christi tempore florvit, et suburbanorum, insigniorumq[ue] historiarum eius breuis descriptio: simvlet locorvm, qvae Iesu Christi et sanctorum passione gestisq[ue] decorata sunt, succinctus commentarius, Köln am Rhein 1584.

6 Ernst Kramer, Kreuzweg und Kalvarienberg. Historische und baugeschichtliche Untersuchung, (Studien zur deutschen Kunstgeschichte, Band 313), Kehl - Strassburg 1957, s. 21.

7 Ulrich Köpf, Heslo Passionsfrömmigkeit, in: Gerhard Müller et al., Theologische Realenzyklopädie, Band XXVII, Politik/Politologie - Publicistik/Presse, Berlin 1997, s. 722-764, cit. 725.

8 Viz Kirschbaum (pozn. 4), sl. 653-656, cit. sl. 654. - Jan Royt, Slovník biblické ikonografie, Praha 2006, s. 223 . 
se projevila $\mathrm{v}$ jeho druhé polovině. Konvenovala s uměleckými tendencemi revidujícími vztah ke skutečnosti. Výtvarné zobrazení přestávalo být obrazem předmětného světa, jeho napodobením, a získávalo stále více znakový charakter. Ke slovu se tak dostávaly nové vyjadřovací způsoby. Umělci, kteří se od předmětnosti uchylovali k niterným psychickým procesům, přistoupili k expresivní deformaci. Jiní se stále chápali viděné skutečnosti, ale rovněž ji přetvářeli, aby zdůraznili její metafyzickou stránku. Dospívali mimo jiné k výraznému kompozičnímu zjednodušení, zaměření se na práci s detaily výjevu, se světlem či k závěrečnému ustanovení vlastní symbolické platformy. V konečné fázi snahy po nastolení nového světa, akcentujícího především nepředmětnou sféru, vedla transformace $\mathrm{k}$ úplnému rozkladu formy a abstraktnímu projevu. ${ }^{9}$ Pro pozorovaný problém je také typická modifikace obsahových složek díla. Byt’ výtvarný námět neztratil svoji tradiční denotaci označovat křížovou cestu Ježíše Krista, proměnil se částečně její smysl. Může za to především subjektivní pojetí tématu, do kterého se promítá konceptuální přístup autora nikoli ve významu dematerializace uměleckého díla, ale přesunu podstaty syžetu z fyzického světa do mentálního prostředí.

$\mathrm{V}$ první řadě se budeme věnovat snaze uměleckého ducha po nacházení co možná nejúspornějšího vyjádření komplexní myšlenky, již zahrnují jednotlivá zastavení kř́ížové cesty. Z logiky tohoto uvažování docházelo především k tomu, že byla celá řada významů transformována do symbolického zobrazení nebo výtvarné metafory. Nebylo již tedy cílem navozovat iluzi vnější skutečnosti, ale naopak vnitřní podstaty předmětu, a přirozené čtení obrazů vystřídala nutnost chápat nepřímo vyložené ideje. ${ }^{10}$ Recipient je tak donucen, pokud touží po úplném dekódování vizuální informace, osvojit si specifická interpretační pravidla, která ovšem nenalezne v tradičním textu křrižové cesty, ale v textu rozšiřujícím a doplňujícím výtvarné sdělení, nezřídka kdy pocházejícím prrímo $\mathrm{z}$ rukou umělce.

Realizace Karla Stádníka v kostele Panny Marie Královny míru v Praze-Lhotce (1973$1975)^{11}$ stojí na počátku výtvarné cesty, kterou bychom mohli zjednodušeně nazvat aktualizací tradiční ikonografie tématu. Promýšlení idejí via crucis v konkrétní době a viděno prismatem tohoto období mělo za následek implikaci druhotných významů. To můžeme dále dokumentovat ve zpodobnění Kř́žzové cesty Renaty Bartoňové v kostele sv. Václava v Petrově (2000) či v sérii kovových reliéfů Křižové cesty Petra Cacha v Olešnici (2016). ${ }^{12}$ Zobrazení tématu je ve všech případech konkrétní, nicméně některé části výjevů se zdají být $\mathrm{v}$ kontextu základního př́běhu cizorodé a s námětem zdánlivě nesouvisející, pokud nejsou řádně vyloženy. V prvních dvou případech pozorujeme nápadné vyprázdnění dějové scény kř́ǐzové cesty na úkor upřednostňování předem promyšlených symbolů a alegorií. Smysl Kristova utrpení je zde podtržen bolestí a tragédiemi lidského osudu. Stádník ve své nejlepší realizaci připomněl násilí a válku, Bartoňová člověka hendikepovaného a chorobně závislého. Cach příběh zastavení na popud faráře Lazárka vyměnil za alegorické obrazy líčící kromě lidských těžkostí požáry, povodně a ničení životního prostředí. Rovněž propojení symbolické květomluvy se zastaveními Křižzové cesty Lud-

9 Josef Zvěřina, Dílo jako znak, Praha 1971, s. 69-72.

Ibidem, s. 125-128.

11 František Tomášek - Jan Lebeda, Velikonoční cesta, Praha 1982.

12 Renata Bartoňová - Josef Veselý, Křízová cesta pro tebe i pro mne, Petrov u Strážnice 2001. - Pavel Lazárek - Zdeněk Peša, Kř́žzová cesta bolestí regionu Olešnicka, Olešnice 2016. 
mily Jandové v kostele Navštívení Panny Marie v Bohuslavicích u Zlína ${ }^{13}$ se neobejde bez přidané interpretace. Jandová ovšem postupovala opačně. Tragičnost námětu nezesilovala přidanými výjevy, ale utajila ji a zjemnila v ř́ŕši rostlin. [Obr. 1]

Ve smyslu maximální koncentrace námětu lze zajít ještě dále. Lapidární pojetí zastavení Kř́žové cesty v podobě nízkého bronzového reliéfu realizoval v roce 2017 Vladimír Kokolia pro kostel sv. Václava v Sazovicích na Zlínsku. ${ }^{14}$ Stejně jako Ludmila Jandová v nedalekých Bohuslavicích měl autor v rukou koncept i realizaci nástěnné výzdoby chrámu. Do čistého architektonického prostoru hledal výtvarnou formu podporující imaginaci a záměrně se soustředil na vizuální úspornost. Zastavení jsou tvořena jednoduchými motivy sevřenými v malém kompaktním tvaru. Přibíjení Ježíše Krista na kříž je zpodobeno pouze jako obrys ruky s ránou v dlani. S pojetím prázdného a plného prostoru variují i následující tř̌i zastavení. Korpus Kristova ukřižovaného těla je zahloubený do objemu kříže a zdá se tak ve své bolesti velmi malým. Proti tomu stojí vzkř́íšený Kristus nad hlavním oltářem, který svojí velikostí křištálově průzračný kříž přesahuje. Zajímavým motivem je vyřešen děj třináctého zastavení, v němž je Ježíšovo tělo jakoby roztaženo před divákem spolu s pohřebním rubášem. Do něj je v posledním zastavení Boží Syn zabalen a následně uložen do hrobu. $\mathrm{V}$ tomto prrípadě přistupuje do znakového pole rovněž způsob umístění souboru po obvodu zdi, kde je každé zastavení situováno vždy o trochu výš než to předchozí, aby se tak zdůraznil směr chůze Ježíše Krista na Golgotu, tedy do kopce. [Obr. 2]

Práce Mikuláše Medka pro kostel sv. Josefa v Senetářově (1971) se stala východiskem uměleckého směřování, které opouštělo předmětnou realitu tohoto světa se snahou ji překonat a vytvořit si realitu vlastní. Autor položil důraz na působení strukturální černé malby prostoupené pouze třemi barvami (červenou, modrou, zlatou), v nich nechal působit několik symbolů $\mathrm{v}$ podobě trnové koruny, kříže, Veroničiny roušky, očí jeruzalémských žen, kostek a hřebů, naznačujících konkrétní situace na Kristově poslední cestě. Jak sám Medek napověděl ve vysvětlujícím textu, ${ }^{15}$ spatřoval paralely mezi utrpením Ježíše Krista a svým životem v perzekvované společnosti, jež ho donutila žít v izolaci od výtvarného světa. Při tvorbě jej ovlivňoval i postupně se zhoršující zdravotní stav. Autor do tvorby projektoval své nitro a tím dokázal stvořit artefakt silně působící na diváka, zjevující a zároveň skrývající vnitřní děj jednotlivých obrazů. Na hledání barevných či předmětných metafor v daném tématu se zaměřil i Aleš Lamr v roce $2001 \mathrm{v}$ realizaci pro obnovenou Kř́žovou cestu v Horním Maršově. V roce 2012 došlo v jeho druhém souboru Kř́žové cesty $\mathrm{k}$ vymizení znaků existující reality a výtvarná forma se podvolila již pouze materiální struktuře. Během výtvarné artikulace tématu došel k symbolickému zobrazení také Zdeněk Gajdoš v realizaci Křižové cesty pro kapli sv. Jana Pavla II. v Bukovanech (2013). ${ }^{16}$ Duši Ježíše Krista zde autor zpodobnil v symbolu kruhu, který prochází jednotlivými zastaveními. V průběhu cesty jeho forma reaguje na prožité události a kruh se postupně zvětšuje až na polokouli, jež opanuje celý prostor kompozice a vytlačuje z něj všechny ostatní prvky. Médium krčeného bleděmodrého papíru do souboru děl přináší i něco

Ludmila Jandová - Josef Suchý, Kř́žová cesta, Březnice 2004.

4 Zdeňka Jančíková, Kostel sv. Václava Sazovice, Sazovice 2017.

15 Antonín Hartmann, Jedovnice - Kotvrdovice - Senetářov, in: Vratislav Effenberger - Anna Fárová et al., Mikuláš Medek (kat. výst.), Galerie Rudolfinum Praha 2002, s. 169-173.

16 Josef Kouřil - Lubomír Jarcovják (edd.), Bukovany. Kaple sv. Jana Pavla II, Zlín 2014, s. 80. 
ze své křehkosti a barevné proměnlivosti, což bylo rovněž autorským záměrem. [Obr. 3] V Bukovanech u Hodonína se nachází ještě o něco málo starší realizace kř́ižové cesty v podobě skupiny 14 sousoší umístěných v exteriéru na hranici lesa směrem ke kapličce sv. Anny. ${ }^{17}$ I zde můžeme pozorovat samotné umístění zastavení jako důležitého znaku, ve kterém jsou vzpomenuty poutnické podmínky jeruzalémské Via dolorosa v nutnosti překonat jednotlivé úseky chůzí do kopce. Po formální stránce se autor Lubomír Jarcovják přiklonil již čistě $\mathrm{k}$ abstraktnímu projevu, ze kterého vynechal všechny před tím používané symboly. Soustředil se pouze na schopnost geometrických tvarů a základních tektonických principů definovat prostor a svým výrazem sdělit divákovi obsaženou ideu. [Obr. 4] Ve stejné době, v roce 2009, pracovali na realizaci Kř́žové cesty Pavla Kačírková s Janem Ambrůzem v Šarovech u Zlína. ${ }^{18}$ Zvolili opět prostou výtvarnou podobu a podél cesty do kopce nad vsí vztyčili sérii čtrnácti betonových křížů provedených pouze v obrysovém tvaru. Jejich prázdný vnitřní prostor zachovává předem promyšlený rozměr, ve kterém je možné postavit vzpřímenou lidskou figuru. Mezi jinými významy se v této formě konkretizuje rovněž historický vzhled památníků kř́ižové cesty v Jeruzalémě. ${ }^{19}$ [Obr. 5]

Připomeňme si nyní Kř́žovou cestu Romana Týce (2010), který se uchýlil k využití audiovizuálních médií a formy happeningu namísto klasických výtvarných technik. Jeho projekt byl rozložen do dvou oddělených fází. Nejprve si nechal v průběhu osobní body-artové akce hřebíkem probodnout dlaň a prýštící krev následně využil pro uměleckou tvorbu. Konkrétně zanechával krvavou stopu na připravených bílých papírových podložkách. Druhá fáze projektu představovala vystavení velkoformátových plakátů $s$ vybranými vyzvětšovanými krvavými skvrnami pojmenovanými jako jednotlivá zastavení křižové cesty. Jelikož se jednalo o ilegální výlep na oficiálních plakátovacích plochách v tramvajových zastávkách v Praze-Karlíně, krátký film, který o celé akci autor natočil, publikoval až po promlčení dvouleté lhůty trestní odpovědnosti. Koncept autora odrážel jeho osobní angažovanost v boji proti stereotypům ve vnímání okolního světa zahlceného vizuálním a informačním smogem. Stejně tak projekt konvenoval s jeho osobním životním postojem promýšleným v horizontu 33 let, tedy stejného věku, kdy přinesl Ježíš Kristus nejvyšší obět na křiži. Další odlišností Týcova uměleckého záměru je fungování v čase a prostoru. Jeho Křžžová cesta se nestala součástí sakrálního prostředí jako realizace zmíněné výše. Šlo především o jednorázovou veřejnou akci, která byla později připomenuta velkoformátovými plakáty na krátkodobé výstavě Egon Schiele Art Centra v Českém Krumlově a funguje rovněž jako videozáznam na internetové síti. ${ }^{20}$

Pokusíme se nyní shrnout zásadní společné body a interpretovat jednu z důležitých proměn zobrazování křížové cesty, které se odehrály po polovině 20. století. Především

17 Lubomír Jarcovják, Bukovany Kř́žzová cesta, [Bukovany] 2010.

18 Jan Ambrůz - Pavla Kačírková, Jinákrajina / Šarovy, Lhota, Salaš, Bohuslavice/, Jinákrajina, http:// www.jinakrajina.eu, vyhledáno 20. 12. 2017.

19 Viz Kramer (pozn. 6), s. 14-16. - Wilhelm Ziehr, Kř́ž: Symbol: Zobrazování: Význam, Kostelní Vydří 1997, s. 170-176.

20 Roman Týc, Křížová cesta (Way of the Cross), YouTube, 1. 4. 2010, https://www.youtube.com/watch? v=quCQrxpfEhQ, vyhledáno 20. 12. 2017. - Radek Wohlmuth, Velikonoce: Roman Týc a kř́žzová cesta, Týden, 5. 4. 2010, https://www.tyden.cz/rubriky/kultura/umeni/velikonoce-roman-tyc-a-krizova -cesta_164257.html, vyhledáno 20. 12. 2017. - Václav Koblenc, Týc: chtěl jsem si prožít křížovou cestu, Českobudějovický deník, 11. 3. 2010, https://ceskobudejovicky.denik.cz/kultura_region/tyc -chtel-jsem-si-prozit-krizovou-cestu20100310.html, vyhledáno 20. 12. 2017. 
můžeme konstatovat, že závažnou skutečností tohoto nového obrazu křížové cesty je komplikovaný umělecký koncept, který vkládá rozhodující tvůrčí roli do rukou subjektu, a to jak původce díla, tak jeho pozorovatele. Vyjádření vnitřních skutečností a překonání předmětné reality dalo vzniknout novému znakovému systému, který potlačuje tradiční představu křížové cesty a není součástí původního náboženského textu, jenž živil ikonografii námětu dlouhou dobu před tím. Podstatnou součástí takového díla se tak jeví slovní popis. Ten je nutným vysvětlujícím doplňkem ozřejmujícím vznikající interpretační mezery mezi divákem a dílem.

Uvedené okolnosti v nás vzbuzují otázky po podstatě sakrálního umění tohoto druhu. Můžeme se ptát, zda jsou takovými artefakty uspokojeny kultické potřeby vnímatele? Dochází k potřebné evokaci duchovních a psychických významů? Shrneme-li to vše do nejdůležitější otázky, dokáže takové umělecké dílo komunikovat na srozumitelné úrovni? Zodpovězení formulovaných otázek nám umožňuje pochopit nejednoznačné přijetí zmíněných realizací křížových cest. To se na pomyslné stupnici pohybuje od přijetí až k úplnému odmítnutí, jak nejlépe dokumentuje př́ípad Kř́žové cesty v Šarovech. ${ }^{21}$

\section{LITERATURA}

Christiaan van Adrichem, Iervsalem, sicvt Christi tempore florvit, et suburbanorum, insigniorumq[ue] historiarum eius breuis descriptio: simvlet locorvm, qvae Iesu Christi et sanctorum passione gestisq[ue] decorata sunt, succinctus commentarius, Köln am Rhein 1584.

Renata Bartoňová - Josef Veselý, Kř́žzová cesta pro tebe i pro mne, Petrov u Strážnice 2001.

Martha Bayless (ed.), Collectanea pseudo-Bedae, Dublin 1998.

Iohannes de Caulibus, Meditationes uitae Christi, Augsburg 1468.

James D. Douglas (ed.), Nový biblický slovník, Praha 2009.

Vratislav Effenberger - Anna Fárová et al., Mikuláš Medek (kat. výst.), Galerie Rudolfinum Praha 2002.

Zdeňka Jančíková, Kostel sv. Václava Sazovice, Sazovice 2017.

Ludmila Jandová - Josef Suchý, Kř́žová cesta, Březnice 2004.

Lubomír Jarcovják, Bukovany Křížová cesta, [Bukovany] 2010.

Engelbert Kirschbaum (ed.), Lexikon der christlichen Ikonographie: allgemeine Ikonographie. Bd. 2, Fabelwesen-Kynokephalen, Rom 1990.

Josef Kouřil - Lubomír Jarcovják (edd.), Bukovany. Kaple sv. Jana Pavla II, Zlín 2014.

Ernst Kramer, Kreuzweg und Kalvarienberg. Historische und baugeschichtliche Untersuchung, (Studien zur deutschen Kunstgeschichte, Band 313), Kehl - Strassburg 1957.

Gerhard Kroll, Po stopách Ježíšových, Kostelní Vydří 2002.

Pavel Lazárek - Zdeněk Peša, Kř́žová cesta bolestí regionu Olešnicka, Olešnice 2016.

Gerhard Müller et al., Theologische Realenzyklopädie, Band XXVII, Politik/Politologie - Publicistik/ Presse, Berlin 1997.

Jan Pascha, Pelgrimsreis naar het heilige land (Peregrinatio spiritualis), Brussel 1593 [?].

Jan Royt, Slovník biblické ikonografie, Praha 2006.

Kurt Schubert, Bible a dějiny, Svitavy 2000.

František Tomášek - Jan Lebeda, Velikonoční cesta, Praha 1982.

Wilhelm Ziehr, Kř́ž: Symbol: Zobrazování: Význam, Kostelní Vydří 1997.

Josef Zvěřna, Dílo jako znak, Praha 1971.

21 Hana Minaříková, Obyvatelé Šarov: Kř́žovou cestu nechceme, Zlínský deník, 22. 11. 2008, https:// zlinsky.denik.cz/zpravy_region/obyvatele-sarov-krizovou-cestu-nechceme20081121.html, vyhledáno 20. 12. 2017. 


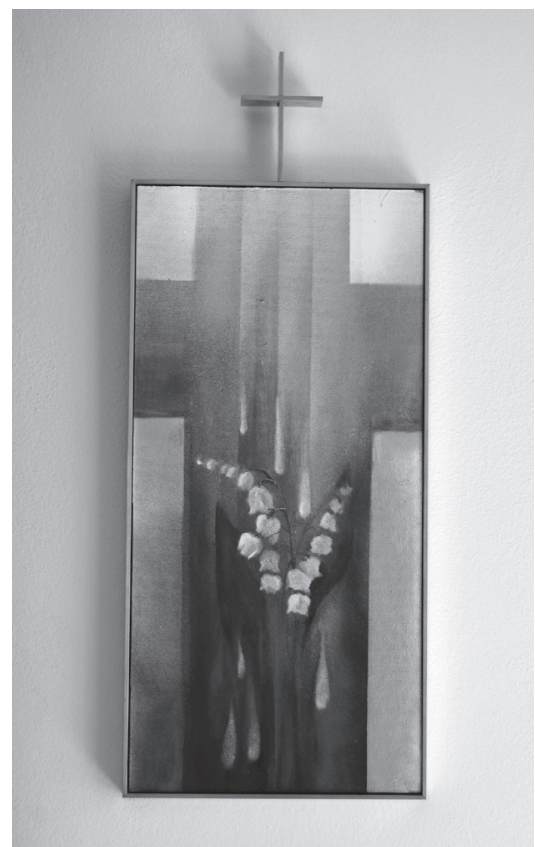

Obrázek 1: Ludmila Jandová, VIII. zastavení křížové cesty, 2004, olejomalba, kaple Navštívení Panny Marie v Bohuslavicích u Zlína, Rímskokatolická farnost Březnice. Foto: Hana Lamatová

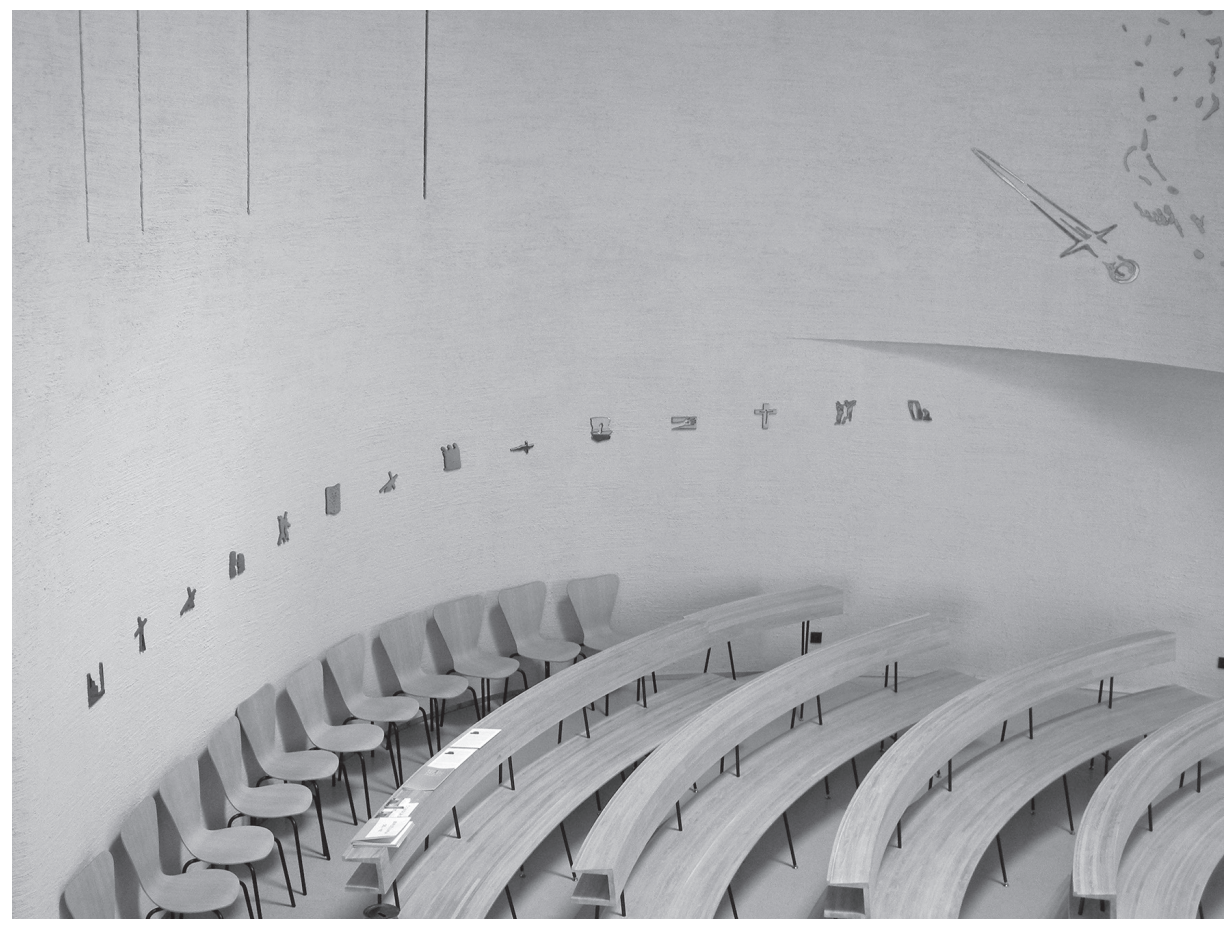

Obrázek 2: Vladimír Kokolia, Zastavení křížové cesty, 2017, bronzový reliéf, kostel sv. Václava v Sazovicích u Zlína, Rímskokatolická farnost Mysločovice. Foto: Hana Lamatová 

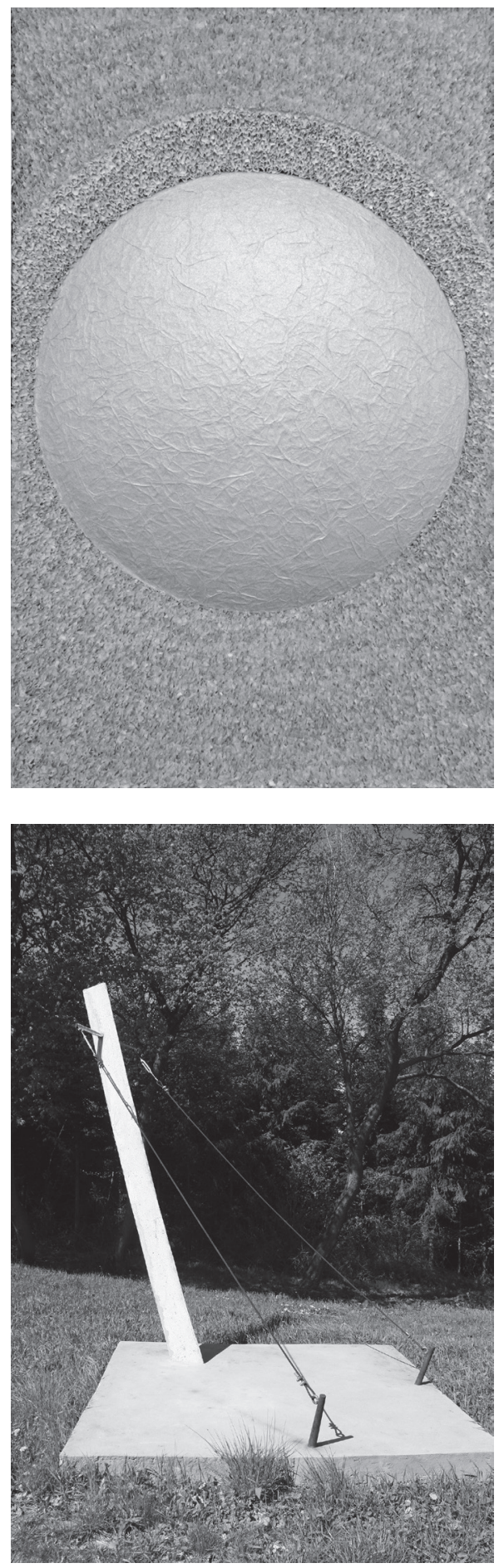

Obrázek 3: Zdeněk Gajdoš, XIV. zastavení křižžové cesty, 2013, papírový reliéf, kaple sv. Jana Pavla II. v Bukovanech, Rímskokatolická farnost Kyjov. Foto: Hana Lamatová

Obrázek 4: Lubomír Jarcovják, XIII. zastavení křížové cesty, 2009, betonová socha, Kř́ižová cesta v Bukovanech, Římskokatolická farnost Kyjov. Foto: Hana Lamatová 


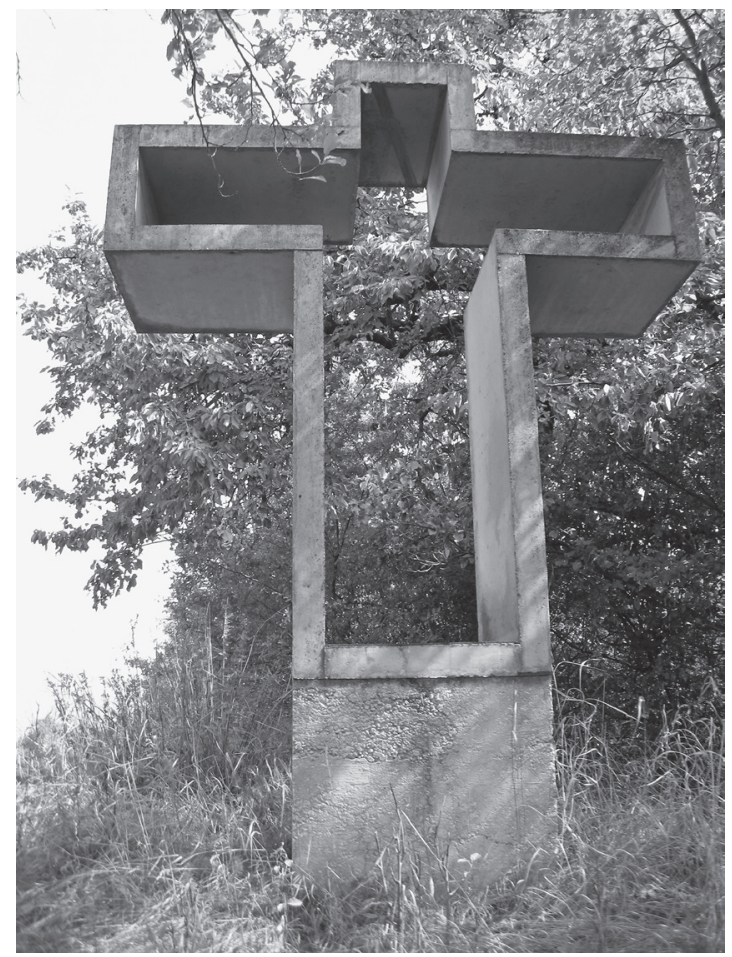

Obrázek 5: Jan Ambrůz - Pavla Kačírková, VIII. zastavení křrižové cesty, 2009, betonová socha, Kř́ižová cesta v Šarovech u Zlína, Rímskokatolická farnost Březnice. Foto: Hana Lamatová 